Vol.46, n. 4 : pp. 705-710, December 2003 ISSN 1516-8913 Printed in Brazil
BRAZILIAN ARCHIVES OF BIOLOGY AND TECHNOLOGY

AN INTERNATIONAL JOURNAL

\title{
Plants and Pollinating Bees in Maringá, State of Paraná, Brazil
}

\author{
Vagner de Alencar Arnaut de Toledo ${ }^{1 *}$, Adriano Ernesto de Toledo Fritzen ${ }^{1}$, Carolina \\ Antunes Neves ${ }^{1}$, Maria Claudia Colla Ruvolo-Takasusuki ${ }^{2}$, Silvia Helena Sofia $^{3}$ and Yoko \\ Terada $^{2}$ \\ ${ }^{1}$ Department of Animal Science; Universidade Estadual de Maringá - UEM; vaatoledo@ uem.br; Avenida \\ Colombo, 5790; 87020-900; Maringá - PR - Brazil. ${ }^{2}$ Department of Cell Biology and Genetics; Universidade \\ Estadual de Maringá - UEM; Avenida Colombo, 5790; 87020-900; Maringá - PR - Brazil. ${ }^{3}$ Department of \\ Biology; Universidade Estadual de Londrina; Londrina - PR - Brazil
}

\begin{abstract}
The present study was carried out to survey the bees as visitors to melliferous flora in the region of Maringá, state of Paraná, Brazil. A total of 331 insects were captured, and the fauna comprised $39.88 \%$ Trigona spinipes, $38.37 \%$ Apis mellifera, $8.16 \%$ Tetragonisca angustula, 3.93\% Halictidae, 1.21\% Megachilidae, 2.42\% Anthophoridae, and $3.32 \%$ other Hymenoptera. Eleven plant species from nine families were observed. The four families most frequently visited by A. mellifera were Pontederiaceae (93.53\%), Sterculiaceae and Polygoniaceae (47.22\%), Apocynaceae and Apiaceae (42.86\%). The families most visited by T. spinipes were Lamiaceae (64.70\%), Apocynaceae (57.14\%),

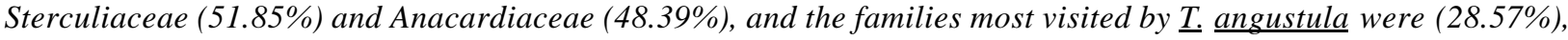
Asteraceae (22.22\%) and Labiatae (16.47\%). Three species predominated in number of bee visits Dombeya wallichii (32.63\%), Ocimum americanum (15.5\%) and Antigonon leptopus (15.2\%). T. angustula was the most frequent visitor of $\underline{\text { O. gratissimum flowers }}(60.87 \%)$.
\end{abstract}

Key words: Stingless bees, pollination, melliferous flora

\section{INTRODUCTION}

The melliferous flora of a certain region is subject to constant changes due to ecological factors and agricultural treatments. Some changes, such as land clearing by burning, monoculture areas and pesticides, strongly affect the native bee species and their populations. On a short-term basis, this may imply a higher dependence on pollination by Apis mellifera and Tetragonisca angustula to ensure good production. Plant pollination by insects is important for better productivity (Nogueira-Couto and Carmona, 1993). Nogueira-
Couto et al. (1988) noticed the need for pollinators in Crotalaria; when pollinators were absent the plant did not produce pods.

Stingless bees are responsible for $30 \%$ to $90 \%$ of plant sexual reproduction in rainforests through pollination and cross-fecundation (Kerr et al., 1994). Bees from the tribe Meliponini, usually associated with rainforest flora, forage according to the resources present, colony necessity and competitors (Roubik, 1981). Bee colonies can make about four million trips per year. During each forager flight, an average of 100 flowers is visited (Free, 1970). Pollen shortages may occur at

\footnotetext{
* Author for correspondence
} 
any time of the year due to environmental factors (Taber and Poole, 1974; Doull, 1975), or due to bee visitations to plants with lots of nectar and little pollen (Stanger and Laidlaw, 1974; Johansson and Johansson, 1977).

Even though pollen and nectar are present at different times of day in different plant species (Free, 1970) and in different places, bees are able to find and gather them due to a well-developed orientation sense and excellent foraging skill (Von Frisch, 1967).

Many plants of economic importance depend upon insects to increase fruit and seed production. Thus, this study was carried out to survey the angiosperms and their insect pollinators in the region of Maringá, state of Paraná, in the south of Brazil to contribute to the understanding of the region's biodiversity.

\section{MATERIAL AND METHODS}

The study was carried out from August 1999 to January 2000 in the campus of Universidade Estadual de Maringá, state of Paraná, Brazil $\left(23^{\circ}\right.$ 55' S., 51 57' W., $542 \mathrm{~m}$ altitude), with a mean annual precipitation of $1677 \mathrm{~mm}$ and a mean temperature of $22^{\circ} \mathrm{C}$. Eleven plant species from nine families were examined: Mangifera indica (Anacardiaceae); Allamanda sp. (Apocynaceae); Tabebuia serratifolia (Bignoneaceae); Cosmos bipinnatus (Asteraceae); Leonorus sibinicu, Ocimum americanum and Ocimum gratissimum (Lamiaceae); Eichornia crassipes (Pontederiaceae); Antigonon leptopus (Polygoniaceae); Dombeya wallichii (Sterculiaceae) and Foeniculum vulgare (Apiaceae). A herbarium was prepared with these species. The collection is housed at the Herbarium of Universidade Estadual de Maringá (HUM). Insect visitors were collected during the flowering of these plants. Each collection (three per plant species) was carried out from 8:30 a.m. to 11:30 a.m. The insects collected were identified and an entomological collection was prepared.

\section{RESULTS}

During the study 331 insects were collected and the bees found in higher percentages were $T$. spinipes $(39.88 \%)$ and A. mellifera $(38.37 \%)$, with
13.59\% corresponding to other Hymenoptera and other insects (Table 1). Fig. 1 shows the percentages of $T$. angustula visits to different flower species. T. angustula was collected at highest frequency on flowers of Ocimum gratissimum $(60.87 \%)$ and Foeniculum vulgare $(28.57 \%)$. The total numbers of insects collected on flowers of different species showed that Trigona spinipes, A. mellifera and T. angustula were the most abundant (Table 1). T. angustula comprised $8.16 \%$ of the total number of insects collected. These bees were not found on flowers of Allamanda sp., L. sibinicus, O. americanum, E. crasseps or D. wallichii (Table 1). T. spinipes may be the main pollinator of $O$. americanum because it was the only species collected on flowers of this plant. This bee can also be considered as a main pollinator of Allamanda (57.4\%), D. wallichii (51.85\%) and $M$. indica (48.39\%), corresponding to about $50 \%$ of all floral visitors to each family (Table 1). A. mellifera was collected on the flowers of all plants except $O$. americanum.

On the basis of the total number of insects gathered on each plant family, as well as its percentage from the total collected/family, it could be seen that the two families with higher percentages of gathered insects were Sterculiaceae $(32.98 \%)$ and Lamiaceae $(25.98 \%)$, for a total of $58.61 \%$ (Table 2).

\section{DISCUSSION}

The three bee species more frequently collected were T. spinipes, A. mellifera and T. angustula. Africanized and stingless bees are likely visitors since they are generalists and overlap greatly in time and place of foraging. They have different recruitment systems or differing responses to pollen or nectar rewards (Roubik, 1978). However, those bees play an important role in pollination.

Meliponini, especially those of small size, usually start their activity later and come back to the hive earlier (Nogueira-Neto, 1970). Temperature, luminosity and relative humidity are factors that affect the external activity of $T$. angustula (Iwama, 1977). These observations confirm the results obtained by Brito and Rego (1992), who also found $T$. spinipes $(58 \%)$ and A. mellifera $(21.4 \%)$ as the bees with the largest number of individuals collected in the cerrado in Barreirinhas, state of Maranhão, in the Northeast of Brazil. 


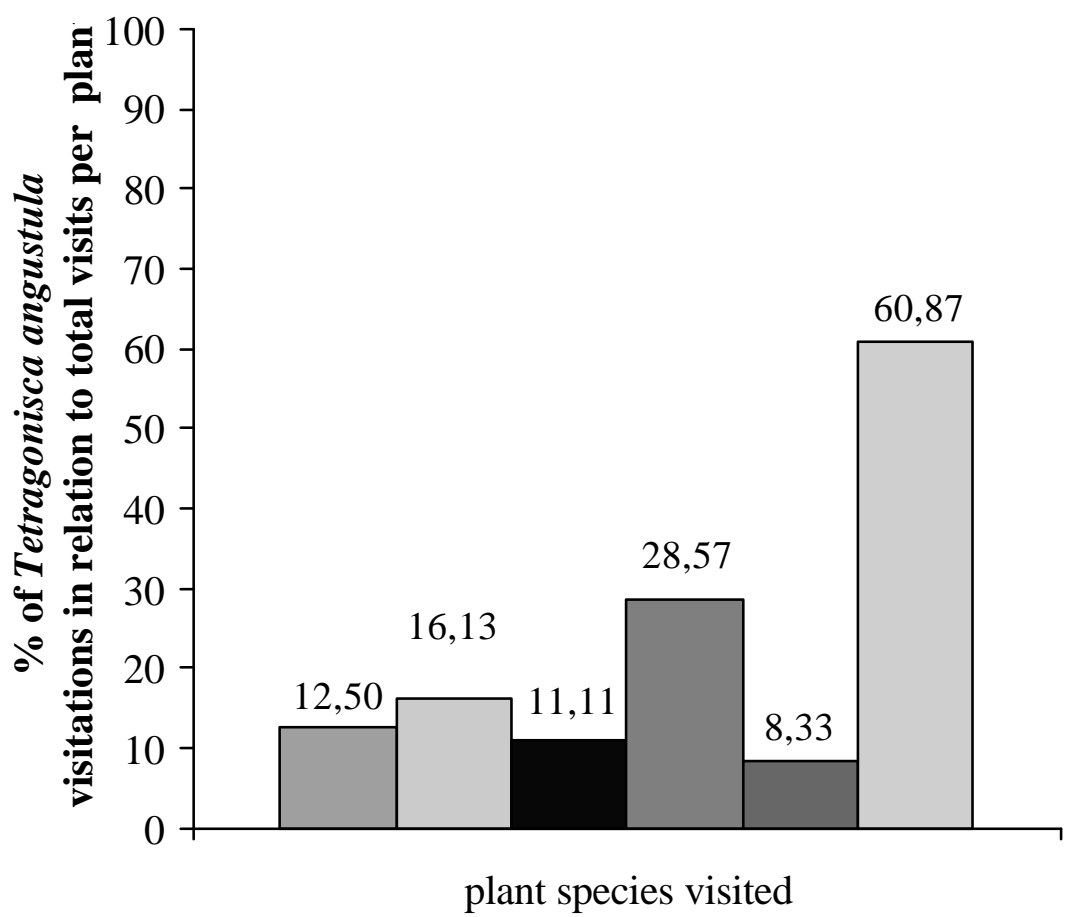

$\square$ Cosmos bipinnatus $\square$ Mangifera indica

- Tabebuia serratifolia

$\square$ Foeniculum vulgare $M$.

$\square$ Antigonom leptopus

$\square$ Ocimum gratissimum $L$

Figure 1 - Percentage of Tetragonisca angustula (Hymenoptera, Meliponini) visitations in relation to total visits per plant from August/99 to January/00 in Maringá, PR, Brazil

Table 1 - Insects collected (\%) from the flowers of different plant families from August/1999 to January/2000, Maringá, PR, Brazil

\begin{tabular}{|c|c|c|c|c|c|c|c|}
\hline Family & Scientific name & $\begin{array}{l}\text { Total no.of } \\
\text { Insects } \\
\end{array}$ & Trigona & Apis & Tetragonisca & Halictidae & $\begin{array}{r}(\%) \\
\text { Megachilidae } \\
\end{array}$ \\
\hline Anacardiaceae & Mangifera indica & 31 & 48.39 & 19.35 & 16.13 & 11.11 & 11.11 \\
\hline Apocynaceae & $\begin{array}{l}\text { Allamanda sp. } \\
\text { Tabebuia }\end{array}$ & 7 & 57.14 & 42.86 & 0.00 & 0.00 & 0.00 \\
\hline Bignoneaceae & $\begin{array}{l}\text { serratifolia } \\
\text { Cosmos }\end{array}$ & 9 & 0.00 & 33.33 & 11.11 & 0.00 & 0.00 \\
\hline Asteraceae & $\begin{array}{l}\text { bipinnatus } \\
\text { Leonorus }\end{array}$ & 16 & 12.50 & 37.50 & 12.50 & 0.00 & 0.00 \\
\hline Lamiaceae & $\begin{array}{l}\text { sibinicus } \mathrm{L} . \\
\text { Ocimum }\end{array}$ & 9 & 0.00 & 55.56 & 0.00 & 0.00 & 3.23 \\
\hline Lamiaceae & $\begin{array}{l}\text { americanum } \\
\text { Ocimum }\end{array}$ & 54 & 100.00 & 0.00 & 0.00 & 0.00 & 0.00 \\
\hline Lamiaceae & $\begin{array}{l}\text { gratissimum } \mathrm{L} . \\
\text { Antigonom }\end{array}$ & 23 & 4.35 & 17.39 & 60.87 & 28.57 & 0.00 \\
\hline Polygoniaceae & $\begin{array}{l}\text { leptopus } \\
\text { Eichornia }\end{array}$ & 36 & 0.00 & 47.22 & 8.33 & 9.26 & 1.85 \\
\hline Pontederiaceae & $\begin{array}{l}\text { crassipes } \\
\text { Dombeya }\end{array}$ & 31 & 0.00 & 93.55 & 0.00 & 0.00 & 0.00 \\
\hline Sterculiaceae & $\begin{array}{l}\text { wallichii } \\
\text { Foeniculum }\end{array}$ & 108 & 51.85 & 47.22 & 0.00 & 0.00 & 0.00 \\
\hline Apiaceae & vulgare M. & 7 & 0.00 & 42.86 & 28.57 & 0.00 & 0.00 \\
\hline Total & & 331 & 39.88 & 38.37 & 8.16 & 3.93 & 1.21 \\
\hline
\end{tabular}




\begin{tabular}{lccccccc}
\hline Cont. Table 1) & $\begin{array}{c}\text { Insect species } \\
\text { Anthophoridae }\end{array}$ & $\begin{array}{c}\text { Coccinellida } \\
\text { e }\end{array}$ & $\begin{array}{c}\text { Oedemer } \\
\text { Vespidae }\end{array}$ & $\begin{array}{c}\text { idae } \\
\text { Corizidae }\end{array}$ & Sphecinae & Other insects \\
\hline Anacardiaceae & 0.00 & 33.33 & 0,00 & 0,00 & 0,00 & 0,00 & 0,00 \\
Apocynaceae & 0.00 & 0.00 & 0,00 & 0,00 & 0,00 & 0,00 & 0,00 \\
Bignoneaceae & 1.85 & 1.85 & 0,00 & 1,85 & 0,00 & 0,00 & 3,70 \\
Asteraceae & 12.50 & 0.00 & 12,50 & 0,00 & 6,25 & 0,00 & 6,25 \\
Lamiaceae & 0.00 & 0.00 & 0,00 & 0,00 & 0,00 & 0,00 & 9,68 \\
Lamiaceae & 0.00 & 0.00 & 0,00 & 0,00 & 0,00 & 0,00 & 0,00 \\
Lamiaceae & 14.29 & 0.00 & 0,00 & 0,00 & 0,00 & 0,00 & 14,29 \\
Polygoniaceae & 3.70 & 0.00 & 0,00 & 0,00 & 0,00 & 0,00 & 0,00 \\
Pontederiaceae & 0.00 & 0.00 & 11,11 & 0,00 & 0,00 & 0,00 & 11,11 \\
Sterculiaceae & 0.00 & 0.00 & 0,00 & 0,00 & 0,00 & 0,00 & 2,78 \\
Apiaceae & 0.00 & 0.00 & 4,35 & 0,00 & 0,00 & 4,35 & 0,00 \\
\hline Total & 2.42 & 1.21 & 1,21 & 0,30 & 0,30 & 0,30 & 2,72 \\
\hline
\end{tabular}

Table 2 - Plant families observed from August/99 to January/00 in Maringá, PR, Brazil, number of insects collected and percentage (\%) of the total

\begin{tabular}{lcc}
\hline \multicolumn{1}{c}{ Botanical family } & Number of insects collected & \% of the total \\
\hline Anacardiaceae & 31 & 9.37 \\
Apocynaceae & 7 & 2.11 \\
Bignoneaceae & 9 & 2.72 \\
Asteraceae & 16 & 4.83 \\
Lamiaceae & 86 & 25.98 \\
Polygoniaceae & 36 & 10.88 \\
Pontederiaceae & 31 & 9.37 \\
Sterculiaceae & 108 & 32.63 \\
Apiaceae & 7 & 2.11 \\
\hline Total & 331 & 100.00 \\
\hline
\end{tabular}

Carvalho and Bego (1992) obtained similar results for 1226 individuals collected 75 botanical species in a region of cerrado in Panga ecological park (Uberlandia, Minas Gerais, Brazil). Sterculiaceae was the most visited family, and also the one that showed the largest number of collected individuals.

T. spinipes could be considered the main pollinator agent of $O$. americanum, Allamanda, D. wallichii and $M$. indica. Among the plant families observed, A. mellifera was the main pollinator of $L$. sibinicus and E. crassipes (93.55\%). T. angustula is considered to be a generalist because it visited flowers of several plants for resources (CortopassiLaurino, 1982). Some plant families such as Euphorbiaceae were preferred in its diet (Knoll, 1990). In Maringá and the surrounding area, this bee preferred Lamiaceae $(60.87 \%)$, Apiaceae
(28.57\%), Anacardiaceae (16.13\%) and Asteraceae $(12.50 \%)$ as food resources.

We found that $16.13 \%$ of T. angustula bees were collected on flowers of Anacardiaceae. These results agree with those of Carvalho and Marchini (1999), who observed T. angustula gathering pollen from Anacardiaceae plants. Slaa et al. (2000) compared the pollinating activity between two species of stingless bees (Nannotrigona testaceicornis and Tetragonisca angustula) and honey bees (A. mellifera) on the ornamental plant Salvia farinacea var. strata (Laminaceae) in enclosures. The plant visit rate of A. mellifera was almost twice as high as that of $T$. angustula. Comparison of the bees showed that pollination by A. mellifera was the most effective. It was suggested that the lower seed production obtained with stingless bees in comparison with honey bees might have been a consequence of their lower 
foraging activity, which in turn was probably related to their much smaller population of foragers. Seed yield evaluated per unit of foraging activity was similar for all three species of bees.

\section{RESUMO}

As abelhas sem ferrão são responsáveis por cerca de $30-90 \%$ da reprodução dos vegetais nas florestas tropicais, através do mecanismo de polinização, na fecundação cruzada (Kerr et al., 1994). Esse trabalho teve o objetivo de realizar um levantamento de angiospermas e os insetos que as polinizam na região de Maringá, $\mathrm{PR}$, com o intuito de contribuir com o entendimento da biodiversidade dessa região. As abelhas foram coletadas entre agosto de 1999 a janeiro de 2000, com o auxílio de uma rede entomológica, durante suas visitas às flores. As coletas foram semanais. Foram coletados 331 insetos, dos quais 39,88\% eram Trigona spinipes, 38,37\% Apis mellifera, 8,16\% Tetragonisca angustula, 3,93\% Halictidae, 1,21\% Megachilidae, 2,42\% Anthophoridae e $3,32 \%$ de outros Hymenoptera. Foram observadas 11 espécies vegetais pertencentes a nove famílias. As quatro famílias mais visitadas pelas abelhas $A$. mellifera foram Pontederiaceae - 93,55\%, Lamiaceae - 55,56\%, Sterculiaceae e Polygoniaceae - 47,22\%; por T. spinipes foram Lamiaceae - 63,95\%, Apocynaceae - 57,14\%, Sterculiaceae - $51,85 \%$ e Anacardiaceae - 48,39\% e por T. Angustula, Lamiaceae - 60,87\%, Apiaceae - 28,57\%, Anacardiaceae - 16,13\% e Asteraceae - $12,50 \%$. Três espécies vegetais foram predominantes em número de visitas pelas abelhas, concentrando $61,7 \%$ das visitas, destacando-se: Dombeya wallichii (32,63\%), Ocimum americanum $(16,31 \%)$ e Antigonon leptopus $(10,88 \%)$. T. angustula foi o visitante mais freqüente $(60,87 \%)$ em $O$. gratissimum.

\section{REFERENCES}

Brito, C. and Rego, M. M. C. (1992), Fauna e flora apícola do cerrado, Barreirinhas - MA (Apoidea, Hymenoptera). Trabalho apresentado no Encontro Brasileiro sobre Biologia de Abelhas e Outros Insetos Sociais, Instituto de Biociências - UNESP, Rio Claro e Faculdade de Filosofia, Ciências e Letras de Ribeirão Preto - USP, Ribeirão Preto, Brasil.
Carvalho, C. A. L. and Marchini, L. C. (1999), Tipos polínicos coletados por Nannotrigona testaceicornis e Tetragonisca angustula (Hymenoptera, Apidae, Meliponinae), Piracicaba, São Paulo. Scientia Agrícola, 56 : (3), 717-722.

Carvalho, A. M. C. and Bego, L. R. (1992), Estudo das interações entre a apifauna e a flora apícola em vegetação de cerrado - reserva ecológica do Panga Uberlândia, MG. Trabalho apresentado no Encontro Brasileiro sobre Biologia de Abelhas e Outros Insetos Sociais, Instituto de Biociências - UNESP, Rio Claro e Faculdade de Filosofia, Ciências e Letras de Ribeirão Preto - USP, Ribeirão Preto, Brasil.

Cortopassi-Laurino, M. (1982), Divisão de recursos tróficos entre abelhas sociais principalmente Apis mellifera Linnéu e Trigona (Trigona) spinipes Fabricius (Apidae Hymenoptera). Tese (Doutorado) Instituto de Biociências, Universidade de São Paulo, São Paulo, Brasil.

Doull, K. M. (1975), Pollen supplements. III - Making effective use of supplementary feeding. American Bee Journal, 115 : (3), 88-89, 99.

Free, J. B. (1970), Insect pollination of crops. Academic Press, New York.

Frisch, K. von (1967), The dance language and orientation of bees. Harvard University, Cambridge (Mass).

Iwama, S. (1977), A Influência de fatores climáticos na atividade externa de Tetragonisca angustula (Apidae, Meliponinae). Boletim de Zoologia da Universidade de São Paulo, 2, 189-201.

Johansson, T. S. K. and Johansson, M. P. (1977), Feeding honeybees pollen and substitutes. Bee World, 58, 105-118, 135, 161-164.

Kerr, W. E.; Nascimento, V. A. and Carvalho, G. A. (1994), Há salvação para os Meliponínios? Trabalho apresentado no Encontro Sobre Abelhas. Faculdade de Filosofia, Ciências e Letras de Ribeirão Preto USP, Ribeirão Preto, Brasil.

Knoll, F. R. N. (1990), Abundância relativa, sazonalidade e preferências florais de Apidae (Hymenoptera) em uma área urbana $\left(23^{\circ} 33^{\prime} \mathrm{S} ; 46^{\circ}\right.$ 43’W). Tese (Doutorado) - Instituto de Biociências, Universidade de São Paulo, São Paulo, Brasil.

Nogueira-Couto, R. H. and Calmona, R. C. (1993), Polinização entomófila em pepino (Cucumis sativus L. var. Aodai melhorada). Naturalia, 18, 77-82.

Nogueira-Couto, R. H.; Costa, J. A. and Silveira, R. C. M. (1988), Efeito da polinização sobre a produção de sementes em Crotalaria juncea. Cientifica, 16 : (1), 85-88.

Nogueira-Neto, P. (1970), A criação de abelhas indígenas sem ferrão. 2. ed. São Paulo : Chácaras e Quintais.

Roubik, D. W. (1978), Competitive interactions between neotropical pollinators and Africanized honey bees. Science, 201 : (4360), 1030-1032. 
Roubik, D. W. (1981), Comparative foraging behavior of Apis mellifera and Trigona corvina (Hymenoptera: Apidae) on Baltimora recta (Asteraceae). Revista de Biologia Tropical, 29 : (2), 177-183.

Slaa, E. J.; Sanchez, L. A.; Sandi, M. and Salazar, W. (2000), A scientific note on the stingless bees for commercial pollination in enclosures. Apidologie, 31, 141-142.

Stanger, W. and Laidlaw, H. H. (1974), Supplemental feeding of honeybees. American Bee Journal, 114 : (4), 138-141.

Taber, S. and Poole, H. K. (1974), Rearing and mating of queen and drone honeybees in winter. American Bee Journal, 114 : (1), 18-19.

Received: September 25, 2001; Revised: May 07, 2002; Accepted: July 25, 2003. 